\title{
PENGARUH KEPEMIMPINAN TERHADAP TINGKAT STRESS DAN KOMITMEN KERJA PERSONIL MAKO KOARMADA I TNI ANGKATAN LAUT
}

\author{
Sigit Dandung Utomo ${ }^{1}$, Ermaya Suradinata ${ }^{2}$, Sampara Lukman $^{3}$, Ika Sartika ${ }^{4}$ \\ 1,2,3,4 Institut Pemerintahan Dalam Negeri (IPDN) \\ Email: sigitutomo1979@gmail.com
}

\begin{abstract}
Abstrak
Menurut data yang bersumber dari Koarmada I TNI AL, sepanjang 2015 hingga 2019 ratarata penderita tekanan mental pada personil TNI AL tumbuh sekitar 5,19\% per tahun. Dari hasil penelusuran arsip TNI AL, penderita tekanan mental umumnya disebabkan oleh internal keluarga, masalah ekonomi, sulitnya adaptasi, hingga masalah kepemimpinan di kesatuan yang dirasa kurang mengakomodir aspirasi personel yang bersangkutan. Oleh karena itu penelitian ini berfokus untuk menganalisis pengaruh kepemimpinan terhadap tingkat stress dan komitmen kerja personil Mako Koarmada I TNI Angkatan Laut. Penelitian ini menggunakan metode kuantitatif. Untuk pendekatan kuantitatif sendiri menggunakan teknik estimasi Structural Equation Modeling (SEM) dan tinjauan literatur untuk menjelaskan temuan kuantitatif penelitian ini. Penelitian ini menggunakan data yang bersumber dari 324 responden. Hasil penelitian ini menunjukkan bahwa variabel kepemimpinan berpengaruh signifikan terhadap penurunan tingkat stress, peningkatan komitmen kerja, dan peningkatan kesejahteraan sosial personel Mako Koarmada I TNI AL. Keberhasilan dari komitmen kepemimpinan ini dapat terjadi dalam jangka penjang dan berkelanjutan jika pijakannya berorientasi kepada pengembangan kualitas sumber daya manusia dan organisasi atau yang dikenal dengan kepemimpinan transformatif sebagai konsep baru dalam disertasi ini
\end{abstract}

Kata Kunci: Kepemimpinan, Komitmen Kerja, Tingkta Stress, TNI AL.

\section{Abstract}

According to data sourced from Koarmada I TNI AL, during 2015 to 2019, the average mental pressure sufferer on Indonesian Navy personnel grew by around $5.19 \%$ per year. From the search results of the Indonesian Navy archives, mental stress sufferers are generally caused by internal family, economic problems, difficulty in adapting, to leadership problems in the unit which are deemed not accommodating the aspirations of the personnel concerned. Therefore, this study focuses on analyzing the influence of leadership on the level of stress and work commitment of the Indonesian Navy's Mako Koarmada I personnel. This research uses quantitative methods. The quantitative approach itself uses the estimation technique of Structural Equation Modeling (SEM) and a literature review to explain the quantitative findings of this study. This study uses data sourced from 324 respondents. The results of this study indicate that the leadership variable has a significant effect on reducing stress levels, increasing work commitment, and increasing the social welfare of the personnel of Mako Koarmada I TNI AL. The success of this leadership commitment can occur in the long term and sustainably if the basis is oriented towards the development of the quality of human and organizational resources or what is known as transformative leadership as a new concept in this dissertation.

Keywords: Leadership, Work Commitment, Level of Stress, Indonesian Navy. 


\section{A. PENDAHULUAN}

Tentara Nasional Indonesia pada dasarnya adalah individu-individu yang memiliki tanggung jawab besar untuk menjaga keberlangsungan kehidupan berbangsa dan bernegara, tak terkecuali TNI Angkatan Laut. Aspek kemaritiman, yang mencakup laut dan seluruh isi yang terkandung di dalamnya merupakan aset yang sangat strategis bagi keberlangsungan pereokonomian bangsa, sebagaimana dua pertiga dari total wilayah Indonesia merupakan laut, yang terbentang dari Sabang sampai Merauke. Semangat untuk menjaga kedaulatan bangsa dari ancaman yang datang, baik dari luar maupun dari dalam, merupakan suatu keharusan dan syarat utama yang harus dimiliki oleh setiap prajurit TNI, tak terkecuali prajurit matra laut.

Markas Komando Armada I atau lebih dikenal dengan Koarmada I merupakan salah satu Kotama di jajaran TNI Angkatan Laut yang memiliki wilayah dari kota sabang sampai dengan kota Cirebon yang memiliki sumber daya manusia yang mengawaki baik sarana dan prasarana KRI dan wilayah tersebut. Untuk menjamin terlaksananya kinerja yang positif pada personil Angkatan Laut, maka stabilitas kejiwaan para personil merupakan hal yang sangat fundamental. Dalam penelitiannya, Sherman dkk (2012), menyebutkan bahwa militer adalah bidang pekerjaan yang paling banyak nmenyebabkan stres kepada para personilnya. Sherman dkk (2012), menyebutkan bahwa dari sepuluh profesi yang umumnya dipilih oleh masyarakat, profesi militer masuk diantara lima profesi yang penuh dengan tekanan dan selalu berhubungan dengan bahaya fisik. Soria dkk (2014), menyebutkan bahwa profesi sebagai personil militer merupakan pekerjaan yang paling rentan mengakibatkan stress pada individu dengan rata-rata skor sebesar 84,72 (dari 100 yang merupakan gangguan kejiwaan sempurna), dan berimplikasi pada tindak perilaku yang membahayakan jiwa.

Stress berhubungan luas dalam bidang kesehatan mental yang negatif seperti depresi, kecemasan, gejala fisik, dan bahkan kematian pada kasus-kasus ekstrim tertentu (Folkman \& Moskowitz, 2000). Pada dasarnya, masalah stress bermula dari tidak terpenuhinya kebutuhan psikologis dan fisik, termasuk hubungannya secara sosial. Pemenuhan kebutuhan psikologis khususnya, berkaitan erat dengan psychological well-being seseorang, dimana semakin terpenuhinya kebutuhan psikologis seseorang, maka psychological well-being pun akan semakin meningkat (Ryan \& Deci, 2001). Pada dasarnya, psychological well-being secara teori merupakan konsepsi kriteria kesehatan mental yang positif sebagai bagian dari ciri seseorang yang memiliki kesejahteraan psikologis (Feldman dkk, 2009).

Psychological well-being suatu konsepsi perihal pemenuhan potensi psikologis seseorang, dimana individu dapat menerima kekuatan dan kelemahan yang ada pada dirinya. 
Jika seseorang dapat menerima dirinya apa adanya, maka rasa bahagia pun akan timbul dalam dirinya sebagai akibat dari rendahnya kecemasan atau stress yang disebabkan oleh kurangnya atau ketidak puasan seseorang akan dirinya sendiri, terlebih dengan kelemahan-kelemahan yang dimilikinya(Liu dkk, 2010). Dengan kata lain orang yang mampu menerima kelebihan dan kekurangannya apa adanya akan berusaha menjalani hidup dengan mengoptimalkan potensi diri yang dimiliki sehingga akan timbul kebahagiaan serta kepuasan dalam hidupnya. Berbeda dengan seorang yang kerap kali merasa tidak puas akan dirinya, seringkali merasa khawatir akan kualitas hidup pribadinya, rasa stagnasi berkepanjangan dalam hidup, merasa bosan, kurang berminat dalam menjalani hidup ataupun merasa terisolasi dengan hubungan sosialnya sampai dengan frustasi serta, ketidak mampuan dalam memecahkan masalah seharihari sebagai akibat dari ketidak mampuan dalam mengoptimalkan kemempuan atau potensi psikologisnya (Barling \& Weatherhead, 2016). Pada intinya psychological well-being adalah kemampuan dalam penerimaan diri serta evaluasi positif akan dirinya dalam berbagai peristiwa yang dialaminya (evaluasi terhadap kejadian masa lalu) serta tercapaianya suatu kondisi bahagia tanpa adanya gangguan psikologis yang ditandai dengan keampuan seseorang dalam mengoptimalkan kemampuan fungsi psikologisnya (Hutapea 2011).

O’leary dalam Effendy (2009) mendefinisikan pemimpin dan kepemimpinan sebagai berikut: 1. pemimpin adalah yang ditunjuk dalam suatu kelompok, tim atau organisasi, 2. pemimpin adalah sosok kharismatik yang membuat keputusan yang baik dan mengilhami orang lain untuk mencapai tujuan bersama, 3. kepemimpinan adalah kekuatan untuk berkomunikasi dengan tegas dan mengilhami orang lain, dan 4. kepemimpinan adalah kemampuan untuk mempengaruhi orang lain. Robbins berpendapat bahwa kepemimpinan adalah kemampuan untuk mempengaruhi suatu kelompok untuk mencapai tujuan. (... the ability to influence a group toward the achievement of goals).Konsep utama dari definisi Robbins tersebut adalah terletak pada kata kemampuan, pengaruhdan kelompok. Definisi kepemimpinan yang juga cukup sederhana, dikemukakan Laurie J. Mullins; ... a relationship through which one person influences the behaviour or actions ofother people. Definisi ini menekankan pada konsep hubungan dari seseorang mempengaruhi perilaku atau tindakan orang lain (Robbins, 1994).

Sampai pada tahun 1980-an, kebanyakan pakar mendefinisikan kepemimpinan sebagai sesuatu yang ditekankan pada suatu proses yang rasional dan kognitif. Kepemimpinan dianggap sebagai suatu proses, di mana pemimpin mempengaruhi pengikutnya untuk memberikan keyakinan terhadap keinginan organisasi yang akan dicapai sebagai suatu tujuan bersama (Catano dkk, 2001). 
Sebaliknya, kebanyakan konsepsi tentang kepemimpinan saat ini menekankan pada pengaruh aspek-aspek emosional. Aspek-aspek berpengaruh yang didasarkan kepada nilai (value-based aspects influence) dapat merangsang suatu kelompok atau organisasi untuk melakukan pencapaian kehendaknya secara efektif dan efisien serta berdaya saing (.Bytyqi dkk, 2010). Para pemimpin memberikan semangat kepada pengikut-pengikutnya untuk berkorban secara tulus dan ikhlas untuk menggapai visi dan melaksanakan misi kelompok atau organisasi (Suradinata, 2013).

Konsep tersebut dapat dimisalkan pada para prajurit yang melaksanakan perintah untuk melakukan suatu misi atau tugas yang berbahaya atau yang beresiko tinggi dengan setia dan bersemangat. Dengan keyakinan atas kebenaran terhadap misi yang diemban yakni semangat yang tinggi dan bangga sebagai seorang prajurit, mereka dapat melaksanakan tugasnya dengan gagah berani menghadapi musuh walau maut selalu mengancam kehidupannya (Meyer dkk, 2013). Sifat loyal yang dipegang oleh tentara pun dibentuk dengan proses yang didasarkan kepada nilai nasionalis yang tinggi, semangat korsa yang tinggi, dan prinsip kill or to be kill.

Sepanjang tahun 2015 hingga 2019, terjadi peningkatan gradual pada jumlah personel TNI Angkatan Laut secara keseluruhan, yang ditempatkan di lokasi yang berbeda. Sepanjang tahun 2015 hingga 2019, rata-rata peningkatan jumlah personel TNI Angkatan Laut yang ditempatkan khusus pada Koarmada I mencapai 4,3\%. Hal ini menunjukkan animo yang cukup tinggi bagi masyarakat untuk bergabung bersama TNI Angkatan Laut.

Namun demikian, seiring pada peningkatan jumlah personel yang ada di TNI Angkatan Laut khususnya yang ditempatkan pada Koarmada I, ternyata sejak tahun 2015 terjadi peningkatan yang cukup signifikan pada penderita tekanan mental. Secara rerata, rasio penderita tekanan mental terhadap total personel setiap tahunnya mencapai 5,19\% sepanjang periode 2015 hingga 2019. Peningkatan yang sangat signifikan ini sebagai akibat dari beberapa faktor seperti masalah internal keluarga, masalah ekonomi, sulitnya adaptasi, hingga masalah kepemimpinan di kesatuan yang dirasa kurang mengakomodir aspirasi personel yang bersangkutan.

Dalam penelitian ini terdapat satu gap utama yang menunjukkan bahwa terdapat ketidakselarasan antara pengalaman lapangan pengelolaan sumber daya manusia di lingkungan TNI Angkatan Laut dan teori yang menjelaskan mengenai optimisasi kualitas sumber daya manusia. Basis pendekatan yang digunakan dalam manajemen sumber daya manusia di lingkungan TNI Angkatan Laut selalu berorientasi pada pada kedisiplinan yang tinggi, dan personel TNI Angkatan Laut sangat dituntut untuk bersiap dalam kondisi terburuk 
sekalipun. Dalam tugas pelayaran para personel juga harus siap untuk tidak bertemu dengan keluarga dalam jangka waktu yang relatif lama. Hal ini kemudian menjadi salah satu pemicu terjadinya stress pada prajurit TNI AL. Dalam penelitian yang dilakukan oleh Kartono \& Gulo (1987), disebutkan bahwa stress pada dasarnya adalah suatu kondisi tegang, di mana bentuknya adalah tekanan batin dan konflik.

Belum optimalnya upaya untuk menangani masalah tekanan mental yang terjadi pada personil Koarmada I TNI Angkatan Laut. Hal ini menjadi perhatian khusus dikarenakan hasil temuan trend olahan data pada bagian sebelumnya menunjukkan bahwa peningkatan $1 \%$ pada jumlah personil Koarmada I TNI Angkatan Laut justru akan meningkatkan potensi terjadinya peningkatan tekanan mental sebesar $0,1 \%$. Hal ini memberikan indikasi kuat bahwa penambahan jumlah personel harus dibarengi dengan upaya peningkatan ketahanan mental prajurit. Hal ini menjadi sangat penting karena akan berimplikasi kuat terhadap kinerja prajurit dalam mengemban amanah negara.

Berdasarkan hasil identifikasi masalah diatas maka penulis berusaha untuk mengidentifikasi pengaruh kepemimpinan terhadap tingkat stress dan komitmen kerja personil Mako Koarmada I TNI Angkatan Laut. Adapun tujuan penelitian ini adalah untuk menganalisis besaran pengaruh kepemimpinan terhadap penurunan tingkat stress dan komitmen kerja personil Koarmada I TNI AL.

\section{B. METODE}

Penelitian ini akan menggunakan pendekatan kuantitatif menggunakan teknik estimasi Structural Equation Modeling (SEM) dan tinjauan literatur untuk menjelaskan temuan kuantitatif penelitian ini dengan fokus pada hubungan sebab akibat antara beberapa faktor terhadap kinerja personil militer TNI AL. Data yang digunakan untuk menjadi sumber analisis adalah data primer yang didapatkan melalui instrument kuesioner atau survei. Dalam penelitian yang berbasis kepada kajian sumber daya manusia, faktor-faktor yang digunakan tidak dapat diukur langsung, karena erat kaitannya dengan persepsi. Faktor-faktor yang tidak dapat diukur langsung disebut sebagai faktor laten. Dengan demikian, setiap faktor yang dianalisis harus memiliki tolak ukur atau indikator yang dapat diukur melalui penggunaan skala yang merepresentasikan persepsi responden (Sugiyono, 2016).

Objek penelitian ini adalah personel militer TNI Angkatan Laut golongan/pangkat Tamtama dengan jum;lah responden 324 responden. Adapun teknik pengumpulan data (sampling) menggunakan random sampling dengan populasi mencakup personil Koarmada I TNI AL Strata Tamtama. 


\section{HASIL DAN PEMBAHASAN}

Tahap awal dari bagian pembahasan dalam penelitian ini adalah melakukan deskripsi terhadap seluruh variabel yang digunakan. Sebagaimana telah dijelaskan pada bagian sebelumnya, bahwa penelitian ini menggunakan variabel kepemimpinan (leadership), tingkat stres, dan komitmen kerja. Data yang digunakan di dalam penelitian ini didapatkan dari sebaran kuesioner kepada responden yang merupakan personil TNI Angkatan Laut yang bertugas pada Koarmad I TNI Angkatan Laut sebanyak 324 orang responden. Informasi dari setiap variabel yang digunakan di dalam penelitian ini akan secara lengkap disajikan melalui statistik deskriptif dengan cakupan informasi jumlah observasi, rerata variabel (mean), standar deviasi, nilai maksimum, dan nilai minimum pada setiap variabelnya.

Dalam penelitian ini dilakukan pengujian empiris antara variabel independen yaitu kepemimpinan terhadap variabel dependen yaitu komitmen kerja yang dimoderasi oleh variabel tingkat stress. Di dalam penelitian ini terdapat 64 butir pertanyaan, di mana 20 pertanyaan berasal dari variabel kepemimpinan, 19 pertanyaan dari variabel sosial ekonomi, 15 pertanyaan dari variabel tingkat stress, dan 10 pertanyaan dari varjabel komitmen kerja. Seluruh pertanyaan yang ada di dalam penelitian ini merupakan variabel teramati (observed variable) untuk merepresentasikan variabel laten secara statistik agar dapat dilakukan analisis hubungan sebab akibat antar variabel-variabel tersebut.

\section{Pengaruh Kepeminpinan terhadap Tingkat Stres}

Berdasarkan hasil pengolahan data primer dengan menggunakan teknik estimasi Structural Equation Modeling, didapatkan nilai t-hitung variabel Kepemimpinan sebesar 3,90, dimana hasilnya lebih besar jika dibandingkan dengan nilai t-table (dengan nilai alpha $5 \%$ ) sebesar 1,96. Hal tersebut mengindikasikan bahwa pengaruh Kepemimpinan terhadap Tingkat Stress bersifat signifikan. Di sisi lain nilai dari koefisien variabel Kepemimpinan adalah -0,05. Maka dari itu dapat disimpulkan bahwa peningkatan kualitas kepemimpinan setiap 1 unit akan menurunkan potensi terjadinya stres sebesar 0,05 unit secara signifikan.

Temuan ini menjadi sangat menarik dikarenakan relevansinya dengan banyak penelitian terdahulu. Yang pertama adalah relevansi dengan penelitian yang dilakukan oleh Sherman, Lee, Cuddy, Renshon, Oveis, Gross, dan Lerner (2012,) tentang pengaruh kepemimpinan dalam rangka menurunkan tingkat stress pada sebuah organisasi. Sebagai pemimpin yang menanjak ke posisi yang kuat di kelompoknya, mereka menghadapi tuntutan yang semakin tinggi. Sebagai hasilnya, muncul persepsi umum bahwa pemimpin memiliki tingkat stres lebih tinggi dibanding non-pemimpin (Chiok Fong Loke, 2001). Namun, jika 
pemimpin juga mengalami sense of control yang meningkat - faktor psikologis yang diketahui memiliki efek penahan stress yang sangat kuat - kepemimpinan dapat diasosiasikan dengan tingkat stres yang lebih rendah. Menggunakan sampel unik dari pemimpin nyata, termasuk pejabat militer dan pemerintahan, kami menemukan bahwa, dibandingkan dengan non-pemimpin, pemimpin memiliki tingkat hormon stres kortisol dan hasil pengukuran (laporan) kecemasan yang lebih rendah. Pemimpin yang memegang posisi dengan kuasa lebih besar menunjukkan tingkat kortisol dan kecemasan lebih rendah dibandingkan pemimpin yang memegang posisi dengan kuasa lebih kecil, hubungan yang dijelaskan secara signifikan oleh sense of control lebih besar (Cole \& Bedeian 2007). Secara bersamaan, penemuan ini mengemukakan hubungan yang jelas antara kepemimpinan dan stres, dengan tingkat kepemimpinan yang berbanding terbalik dengan tingkat stres. Penelitian ini mempertegas hasil penelitian yang dilakukan oleh Sherman dkk (2012), bahwa semakin tinggi kepemimpinan maka semakin rendah pula potensi terjadinya stress.

Selain daripada itu hasil daripada penelitian ini juga releven dengan penelitian yang dilakukan oleh oleh Harms dkk (2017), tentang kepemimpinan dalam dunia militer. Mereka menyebutkan bahwa stres telah diimplikasikan sebagai elemen penting dalam fungsi kepemimpinan. Sebaliknya, tingkah laku dari pemimpin telah lama diperdebatkan sebagai faktor besar dalam menentukan tingkat stres dari bawahannya. Kendati luasnya pengakuan bahwa stres dan kepemimpinan memiliki keterkaitan, belum pernah ada usaha sistematis untuk mengorganisasi dan merangkum litaratur-literatur ini. Pada tulisan ini, kami melakukan tinjauan secara meta-analisis hubungan antara tiga konstruk kepemimpinan (kepemimpinan transformasional, pertukaran pemimpin-anggota (leader-member exchange), dan supervisi yang abusif) dengan stres dan burnout (Gill dkk 2006). Hasil analisis kami mengonfirmasi bahwa stres pada pemimpin memengaruhi tingkah laku pemimpin dan tingkah laku kepemimpinan serta hubungan pemimpin-pengikut adalah penentu signifikan dari stres dan burnout pada bawahan. Bergerak dari hasil ini, kami menyarankan cara-cara baru untuk penelitian pada domain ini serta mendiskusikan bagaimana hasil ini dapat memberi masukan praktis terhadap pengembangan pemimpin (Salemm 2015). Dengan demikian kepemimpinan atasan di dalam dunia militer dapat berimplikasi serius kepada bawahan dalam organisasi militer.

Selain daripada itu penelitian ini juga relevan dengan penelitian yang dilakukan oleh Lyons \& Schneider (2009). Studi ini memanipulasi gaya kepemimpinan transformasional dan transaksional untuk melihat pengaruhnya pada performa individu saat mengerjakan tugas yang penuh tekanan, dan terhadap persepsi dukungan sosial, self-efficacy beliefs, emosi, dan 
perkiraan stresor. Sebagai tambahan, studi ini menguji apakah variabel-variabel tersebut memediasi hubungan antara gaya kepemimpinan dan performa. Dua ratus empat belas partisipan diminta menonton video berisi instruksi atas suatu tugas yang penuh tekanan. Video tersebut diperankan oleh aktor yang menggambarkan satu dari tiga gaya kepemimpinan (trasformasional, transactional-contingent reward, transactional-management by exception). Aspek psikologis, emosional, dan motivasional partisipan diukur sebelum mereka terlibat dalam tugas. Kelompok yang gaya kepemimpinan trasformasional berasosiasi dengan performa pengerjaan tugas yang lebih baik, persepsi dukungan sosial yang lebih tinggi, efficacy beliefs yang lebih besar, afek negatif yang lebih rendah, dan perkiraan ancaman yang lebih rendah dibandingkan dengan kelompok transaksional. Model sebabakibat menunjukkan bahwa gaya kepemimpinan memiliki efek langsung, daripada tidak langsung, pada performa pengerjaan tugas. Penelitian ini memperluas penelitian tentang kepemimpinan dengan menyediakan evaluasi eksperimental mengenai keuntungan/kerugian dari kepemimpinan transformasional dan transaksional pada kondisi pengerjaan tugas yang penuh tekanan. Dan oleh karenanya penelitian ini juga mengkonfirmasi bahwa kepemimpinan memiliki signifikansi yang tinggi terhadap tingkat stress sebagai disebutkan bahwa kepemimpinan memiliki dampak langsung terhadap stakeholder yang ada di dalam organisasi (Gardiner \& Tiggeman, 2006).

Dalam perspektif kepemimpinan, kedudukan dan peran pemimpin tampak dominan dan dapat dianggap sebagai salah satu faktor determinan dalam proses manajemen suatu organisasi pemerintahan. Peran yang dominan itu tentu tidak lepas dari karakter dan kapasitas orang yang berkedudukan sebagai pemimpin serta kondisi para pihak yang dipimpin dan situasi kepemimpinan di antara para pihak tersebut. Para pemimpin harus memiliki kesadaran bahwa dapat berperilaku berbeda pada waktu berhubungan terhadap anggota kelompok secara individual dengan berhubungan terhadap kelompok secara keseluruhan. Hal ini tentu dapat difahami dengan menilai perilaku organisasi yang telah terinternalisasi menjadi budaya kerja para anggota organisasi. Perilaku organisasi yang dimaksud tentu tidak terbatas dalam pengertian individu tetapi sekaligus juga mencakup pengertian kelompok-kelompok tertentu dalam organisasi. Misalnya perilaku kerja individu merujuk pada perilaku kerja perseorangan. Sedangkan perilaku organisasi kelompok terhimpun dalam suatu unit kerja tertentu (Bass dkk, 2003).

Dengan demikian dapat ditarik sebuah konsep besar bahwa kepemimpinan sangat diperlukan dengan tujuan: 
a. Mengatasi tantangan instabilitas kondisi mental personil dengan berbagai faktor yang mencakup masalah internal personil (seperti kondisi ekonomi) maupun hubungan interpersonalnya dengan anggota keluarga inti dan dengan orang lain, dan juga yang mencakup dengan lingkungan kerjanya di kesatuan TNI AL.

b. Dalam konteks kepemimpinan ini, seorang pimimpin harus memiliki sense of belonging terhadap kesatuan, sehingga secara psikologis tercipta efek penahan stress yang kuat pada personil, karena merasakan tempat bekerjanya adalah rumah kedua yang dapat dijadikan tempat untuk menurunkan tingkat stress yang ia dapatkan dari kondisi-kondisi di luar pekerjaannya.

c. Untuk dapat terus mempertahankan kepemimpinan yang kuat dan berkualitas dalam jangka panjang, maka dibutuhkan suatu model pendekatan kepemimpinan yang transformatif, di mana jenis kepemimpinan ini selalu berorientasi terhadap peningkatan kualitas organisasi dan sumber daya manusia yang ada di dalamnya.

d. Merealisasikan pendelagasian tugas-tugas keorganisasian dalam melalui pembagian kerja yang dapat meningkatkan partisipasi personil khususnya secara psikologis dalam memajukan organisasi Koarmada TNI AL. Namun hal penting yang harus digarisbawahi adalah pembagian kerja ini harus berdasarkan kepada kompetensi yang relevan. Tugas ini dapat dibagi menjadi dua kelompok besar, yaitu operasional dan staf. Sebagai contoh pada kelompok pekerjaan staf, lebih banyak diisi oleh lulusan perwira karir yang sebelumnya merupakan lulusan diploma/sarjana/pascasarjana dengan kompetensi sesuai dengan keahlian masing-masing untuk menunjang efektivitas dan efisiensi kegiatan organisasi Koarmada I TNI AL, sedangkan untuk aktivitas operasional akan diisi oleh lulusan akademi militer (yang jenjang pendidikan militernya lebih panjang dari tingkat paling dasar) dikarenakan kompetensi pendidikannya murni militer.

\section{Pengaruh Kepemimpinan Terhadap Komitmen Kerja}

Berdasarkan hasil pengolahan data primer dengan menggunakan teknik estimasi Structural Equation Modeling, didapatkan nilai t-hitung variabel Kepemimpinan sebesar 7,72, dimana hasilnya lebih besar jika dibandingkan dengan nilai t-table (dengan nilai alpha 5\%) sebesar. Hal tersebut mengindikasikan bahwa pengaruh Kepemimpinan terhadap Komitmen Kerja bersifat signifikan. Di sisi lain nilai dari koefisien variabel Kepemimpinan adalah 0,39. Maka dari itu dapat disimpulkan bahwa peningkatan 1 unit pada aspek 
kepemimpinan di Koarmada I TNI Angkatan Laut dapat meningkatkan komitmen kerja sebesar 0,39 unit secara signifikan.

Hal ini menunjukkan bahwa secara empiris kepemimpinan dapat meningkatkan komitmen kerja. Ketika bawahan mempersepsikan bahwa atasan memiliki tingkat initiating structure (sebagai salah satu indikator dari kualitas kepemimpinan) yang tinggi, atasan menciptakan lingkungan kerja dengan peraturan formal dan prosedur untuk diikuti (Clinebell dkk,2013). Sebagai hasilnya, karyawan memiliki persepsi terhadap rasa tanggung jawab yang lebih besar dan meningkatkan komitmen afektif. Lewat atasan lah bawahan mulai mengidentifikasi tujuan dari organisasi dan menginternalisasi nilai-nilainya. Tindakan atasan dilihat sebagai tindakan organisasi; di mana organisasi dipersonifikasikan lewat atasan. Bawahan dapat tertarik dan berkomitmen terhadap organisasi karena mereka mempersepsikan bahwa organisasi memiliki nilai-nilai yang serupa dengan yang mereka miliki. Dan oleh karenanya komitmen kerja pada organisasi pun mengalami peningkatan (Afsar dkk, 2018).

Penelitian ini juga memiliki relevansi pada sektor lain, termasuk pada bidang kesehatan. Penelitian ini relevan dengan penelitian yang dilakukan oleh Avolio dkk (2004), berkenaan dengan dampak kepemimpinan terhadap komitmen kerja. Menggunakan sampel 520 perawat yang dipekerjakan oleh rumah sakit publik di Singapura, kami menguji apakah pegembagan psikologis memediasi efek dari kempemimpinan transformasional terhadap komitmen organisasi pada bawahan. Kami juga menguji apakah jarak struktural (kepemimpinan langsung dan tidak langsung) antara pemimpin dan bawahan memoderasi hubungan antara kepemimpinan transformasional dan komitmen organisasi (Emery \& Barker, 2007). Hubungan positif antara kepemimpinan transformasional dan komitemen organisasi mungkin disebabkan karena bawahan langsung cenderung melihat inkonsistensi dalam tingkah laku atasan mereka yang mungkin memengaruhi komitmen yang mereka rasakan terhadap organisasi (Kent \& Chelladurai, 2001). Lebih lanjut, kapabilitas pemberdayaan pada pengawas tingkat rendah dirumah sakit terbatas. Level komitmen organisasi karyawan yang diberdayakan mengkonfirmasi penelitian sebelumnya dimana penelitian-penelitian tersebut menemukan bahwa karyawan yang diberdayakan tampaknya lebih mungkin untuk membalas dengan tingkat komitmen yang lebih tinggi untuk organisasi mereka. Jarak struktural memoderasi hubungan antara kepemimpinan transformasional dan komitmen organisasi disebabkan oleh dimensi organisasi yang berbeda (Indrayanto dkk, 2014), termasuk jarak struktural, dapat memoderasi sifat kepemimpinan organisasi dan sifatnya anteseden dan konsekuensi. Dengan demikian temuan ini semakin mengkonfirmasi 
bahwa peningkatan kepemimpinan dapat meningkatkan komitmen kerja dalam jangka panjang (Cole \& Bedeian, 2007).

Berdasarkan hasil temuan penelitian di atas, kepemimpinan memegang peranan penting dalam upaya:

a. Peningkatan kinerja personil TNI AL. Jika seorang pemimpin memiliki komitmen kepemimpinan yang kuat, maka secara otomatis akan tercipta lingkungan kerja di mana setiap personil memiliki tanggung jawab yang tinggi atas tugas yang diemban, Hal ini dikarenakan personil tidak merasa sepenuhnya "diperintah," namun lebih merasa "dilibatkan" pada suatu aktivitas yang hebat dan membuat diri mereka teraktualisasi dengan sangat baik di lingkungan kerjangan.

b. Bentuk dari dampak kuatnya kepemimpinan adalah persepsi terhadap rasa tanggung jawab yang lebih besar dan meningkatkan komitmen afektif. Lewat atasan lah bawahan mulai mengidentifikasi tujuan dari organisasi dan menginternalisasi nilainilainya.

c. Tindakan atasan dilihat sebagai tindakan organisasi; di mana organisasi dipersonifikasikan lewat atasan, dan dalam jangka panjang bawahan akan terus termotivasi untuk mengambil bagian dari proses yang positif ini.

\section{Peran Kepemimpinan Tranformasional Koarmada I TNI AL}

Dari Hasil penelitian menunjukkan peran kepemimpinan berpengaruh sangat signifikan baik terhadap tingkat stres dan komitmen kerja personil. Hal ini menunjukkan bahwa aspek kepemimpinan sebenarnya memegang peranan yang paling penting dalam organisasi militer, sebagaimana telah diatur di dalam konstitusi yang kemudian diturunkan menjadi nilai-nilai organisasi militer bahwa kepempimpinan di dalam dunia militer memegang peranan yang sangat sentral di dalam perputaran organisasi dan kinerja dalam jangka panjang. Oleh karena itu konsep mengenai kepemimpinan dalam dunia militer yang dapat disajikan adalah aspek mutlak di dalam keberlangsungan organsiasi dalam jangka panjang.

Sebagaimana telah dijelaskan dalam penelitian di atas, bahwa kepemimpinan berpengaruh signifikan terhadap peningkatan komitmen kerja, penurunan tingkat stress, dan peningkatan kesejahteraan sosial. Hal ini bisa terjadi dikarenakan jenis kepemimpinan pada organisasi militer khususnya pada Koarmada I TNI AL di mana kualitas kepemimpinan memang sangat menentukan stabilitas organisasi. Namun demikian, penentuan jenis 
kepempinan harus didasarkan pada fakta lapangan mengenai pola kepemimpinan seperti apa yang saat ini digunakan di dalam organisasi militer khususnya pada Koarmada I TNI AL.

Untuk menentukan jenis kepemimpinan yang ada di dalam organisasi Koarmada I TNI AL, maka terlebih dahulu kita dapat merujuk kepada jenis kepemimpinan yang telah dijelaskan secara teoritis. Menurut Robbins (1994), bahwa jenis kepemimpinan secara garis besar terbagi menjadi empat bagian utama yaitu i) transactional leadership yang merupakan pola kepemimpinan yang memanfaatkan perubahan sosial yang terjadi di sekitarnya, ii) transformational leadership yang merupakan pola kepemimpinan yang mendorong perubahan positif dengan menginsipirasi untuk pencapaian tujuan besar, iii) charismatic leadership yang merupakan pola kepempimpunan di mana antusiasme dan kepercayaan diri seorang pemimpinan mempengaruhi anggota dalam bentuk tertentu, dan iv) visionary leadership yang merupakan pola kepemimpinan untuk menciptakan dan mengartikulasikan visi yang realistis, kredibel, dan menarik untuk pencapaian yang lebih besar di masa mendatang.

Di sisi lain, disebutkan bahwa tugas pokok dan fungsi Koarmada I TNI AL bertitik berat pada aspek pembinaan. Jika kita merujuk kepada definisi pembinaan menurut KBBI (2020), bahwa secara bahasa pembinaan dapat dimaknai sebaga cara, pembaharuan, penyempurnaan, usaha, tindakan, dan kegiatan yang dilakukan secara efisien dan efektif untuk memperoleh hasil yang lebih baik. Dengan demikian, maka dapat disimpulkan bahwa secara konseptual pun, pola kepempinan yang diberlakukan pada Koarmada I TNI AL berorientasi pada mendorong perubahan positif untuk pencapaian tujuan yang lebih besar (lebih baik). Maka dapat disimpulkan bahwa jenis kepemimpinan yang digunakan di dalam organisasi militer Koarmada I TNI AL adalah jenis kepemimpinan transformasional. Oleh karena berorientasi pada pencapaian tujuan yang lebih baik lagi, maka kepemimpinan berdampak signifikan pada peningkatan komitmen kerja dan penurunan tingkat stress, personil Koarmada I TNI AL.

\section{KESIMPULAN}

Berdasarkan hasil penelitian ini, maka dapat dilahirkan sebuah konsep baru berkenaan dengan peran sentral kepemimpinan di dalam organisasi militer, khususnya pada Koarmada I TNI AL. Berdasarkan hasil pengolahan data pada penelitian ini, didapatkan bahwa kepemimpinan berpengaruh signifikan pada seluruh variabel yang ada, yaitu terhadap tingkat stress dan terhadap komitmen kerja dalam jangka panjang. Sebagaimana telah diamanatkan oleh konstitusim bahwa dalam organisasi militer struktur dan garis komando sangatlah kuat, 
dan sepanjang sejalan dengan UUD 1945 dan Pancasila, maka tidak boleh ada bantahan atas setiap instruksi dari pimpinan di dalam organisasi militer. Oleh karena sentralnya peran kepemimpinan dalam organisasi militer, maka kualitas kepemimpinan harus dipastikan sejalan dengan tujuan peningkatan kualitas organisasi dalam jangka panjang. Kepemimpinan yang baik selalu berorientasi pada peningkatan performa di masa mendatang, dengan melibatkan dan memberikan arahan yang baik kepada bawahan. Meruju kepada karakteristik kepemimpinan yang dibutuhkan dan relevan dalam organisasi militer, maka jenis kepemimpinan transformasional dalam organisasi militer adalah yang paling tepat untuk terus meningkatkan komitmen kerja personil TNI AL dalam jangka panjang secara berkelanjutan. Dengan demikian dapat ditarik sebuah konsep besar bahwa kepemimpinan sangat diperlukan untuk membantu mengatasi tantangan instabilitas kondisi mental personil dengan berbagai faktor yang mencakup masalah internal personil (seperti kondisi ekonomi) maupun hubungan interpersonalnya dengan anggota keluarga inti dan dengan orang lain, dan juga yang mencakup dengan lingkungan kerjanya di kesatuan TNI AL.

Dalam konteks kepemimpinan ini, seorang pimimpin harus memiliki sense of belonging terhadap kesatuan, sehingga secara psikologis tercipta efek penahan stress yang kuat pada personil, karena merasakan tempat bekerjanya adalah rumah kedua yang dapat dijadikan tempat untuk menurunkan tingkat stress yang ia dapatkan dari kondisi-kondisi di luar pekerjaannya. Untuk dapat terus mempertahankan kepemimpinan yang kuat dan berkualitas dalam jangka panjang, maka dibutuhkan suatu model pendekatan kepemimpinan yang transformatif, di mana jenis kepemimpinan ini selalu berorientasi terhadap peningkatan kualitas organisasi dan sumber daya manusia yang ada di dalamnya. Hal ini dapat dilakukan dengan pola pembagian kerja yang sesuai dengan kompetensi dan keahlian personil di masing-masing bidang.

\section{DAFTAR PUSTAKA}

Afsar, B., Shahjehan, A., Cheema, S., \& Javed, F. (2018). The Effect of Perceiving A Calling on Pakistani Nurses' Organizational Commitment, Organizational Citizenship Behavior, and Job Stress. Journal of Transcultural Nursing, 29(6), 540-547.

Avolio, B. J., Zhu, W., Koh, W., \& Bhatia, P. (2004). Transformational leadership and organizational commitment: Mediating role of psychological empowerment and moderating role of structural distance. Journal of Organizational Behavior: The International Journal of Industrial, Occupational and Organizational Psychology and Behavior, 25(8), 951-968. 
Barling, J., \& Weatherhead, J. G. (2016). Persistent Exposure to Poverty During Childhood Limits Later Leader Emergence. Journal of Applied Psychology, 101(9), 1305.

Bass, B. M., Avolio, B. J., Jung, D. I., \& Berson, Y. (2003). Predicting Unit Performance by Assessing Transformational and Transactional Leadership. Journal of applied psychology, 88(2), 207.

Bytyqi, F., Reshani, V., \& Hasani, V. (2010). Work Stress, Job Satisfaction and Organizational Commitment Among Public Employees Before Privatization. European journal of social sciences, 18(1), 156-162.

Catano, V. M., Pond, M., \& Kelloway, E. K. (2001). Exploring Commitment and Leadership in Volunteer Organizations. Leadership \& Organization Development Journal.

Chiok Foong Loke, J. (2001). Leadership Behaviours: Effects on Job Satisfaction, Productivity and Organizational Commitment. Journal of nursing management, 9(4), 191-204.

Clinebell, S., Skudiene, V., Trijonyte, R., \& Reardon, J. (2013). Impact of Leadership Styles on Employee Organizational Commitment. Journal of Service Science (JSS), 6(1), 139-152.

Cole, M. S., \& Bedeian, A. G. (2007). Leadership Consensus as A Cross-Level Contextual Moderator of The Emotional Exhaustion-Work Commitment Relationship. The Leadership Quarterly, 18(5), 447-462.

Effendy, K. (2009). Pergeseran Kepemimpinan Desa. Bandung: Indra Prahasta

Emery, C. R., \& Barker, K. J. (2007). The Effect of Transactional and Transformational Leadership Styles on The Organizational Commitment and Job Satisfaction of Customer Contact Personnel. Journal of organizational culture, communications and conflict, 11(1), 77.

Feldman, P. O., Papalia, D. E., \& Olds, S. (2009). Human development. Jakarta: Salemba Humanika.

Folkman, S., \& Moskowitz, J. T. (2000). Stress, Positive Emotion, and Coping. Current Directions in Psychological Science, 9(4), 115-118.

Gardiner, M., \& Tiggemann, M. (1999). Gender differences in leadership style, job stress and mental health in male-and female-dominated industries. Journal of occupational and organizational psychology, 72(3), 301-315.

Gill, A. S., Flaschner, A. B., \& Shachar, M. (2006). Mitigating Stress and Burnout by Implementing Transformational-Leadership. International Journal of contemporary hospitality management.

Harms, P. D., Credé, M., Tynan, M., Leon, M., \& Jeung, W. (2017). Leadership and Stress: A Meta-Analytic Review. The Leadership Quarterly, 28(1), 178-194.

Hutapea, B. (2012). Emotional Intelegence dan Psychological Well-Being pada Manusia Lanjut Usia Anggota Organisasi Berbasis Keagamaan di Jakarta. Jurnal Insan Media Psikologi, 13(2).

Indrayanto, A., Burgess, J., \& Dayaram, K. (2014). A Case Study of Transformational Leadership and Para-Police Performance in Indonesia. Policing: An International Journal of Police Strategies \& Management.

Kartono, K., \& Gulö, D. (1987). Kamus psikologi. Jakarta: Pionir Jaya. 
Kent, A., \& Chelladurai, P. (2001). Perceived Transformational Leadership, Organizational Commitment, and Citizenship Behavior: A Case Study in Intercollegiate Athletics. Journal of sport management, 15(2), 135-159.

Liu, J., Siu, O. L., \& Shi, K. (2010). Transformational Leadership and Employee Well-Being: The Mediating Role of Trust in The Leader and Self-Efficacy. Applied Psychology, 59(3), 454-479.

Lyons, J. B., \& Schneider, T. R. (2009). The Effects of Leadership Style on Stress Outcomes. The Leadership Quarterly, 20(5), 737-748.

Meyer, J. P., Kam, C., Goldenberg, I., \& Bremner, N. L. (2013). Organizational Commitment in The Military: Application of A Profile Approach. Military Psychology, 25(4), 381401.

Robbins, S. P. (1994). Teori Organisasi: Struktur, Desain dan Aplikasi. Jakarta: Arcan.

Ryan, R. M., \& Deci, E. L. (2001). On Happiness and Human Potentials: A Review of Research on Hedonic and Eudaimonic Well-Being. Annual review of psychology, 52(1), 141-166.

Salem, I. E. B. (2015). Transformational Leadership: Relationship to Job Stress and Job Burnout in Five-Star Hotels. Tourism and Hospitality Research, 15(4), 240-253.

Sherman, G. D., Lee, J. J., Cuddy, A. J., Renshon, J., Oveis, C., Gross, J. J., \& Lerner, J. S. (2012). Leadership is Associated with Lower Levels of Stress. Proceedings of the National Academy of Sciences, 109(44), 17903-17907.

Soria, K. M., Hussein, D., \& Vue, C. (2014). Leadership for Whom? Socioeconomic Factors Predicting Undergraduate Students' Positional Leadership Participation. Journal of Leadership Education Winter (14).

Sugiyono. (2016). Metode Penelitian Pendidikan, Pendekatan kuantitatif, Kualitatif, dan $R \& D$. Bandung: Alfabeta

Suradinata, E. (2013). Analisis Kepemimpinan Strategi Pengambilan Keputusan. Sumedang: Alqaprint Jatinangor. 